\title{
Anaerobranca gottschalkii sp. nov., a novel thermoalkaliphilic bacterium that grows anaerobically at high $\mathrm{pH}$ and temperature
}

\author{
Steffen G. Prowe† and G. Antranikian
}

Institute of Technical Microbiology, Technical University HamburgHarburg, Denickestrasse 15, D-21071 Hamburg Germany
Author for correspondence: G. Antranikian. Tel: +49 4042878 3117. Fax: +49 40428782582. e-mail: antranikian@tu-harburg.de

A novel thermoalkaliphilic, obligately anaerobic bacterium was isolated from a humid soil sample of a hot inlet of Lake Bogoria, Kenya. The newly isolated strain grows optimally at $\mathrm{pH} 9.5$ and $50-55{ }^{\circ} \mathrm{C}$ and its growth range is pH 6.0-10.5 and $30-65^{\circ} \mathrm{C}$. Unlike the already known thermoalkaliphiles, the strain grows heterotrophically on a variety of mono- and polysaccharides (glucose, ribose, mannose, fructose, sucrose, maltose, starch, pullulan, xylan and cellulose) and on proteinaceous substrates such as yeast extract, peptone and tryptone. No dissimilatory sulfate reduction was observed, whereas thiosulfate was found to enhance growth when glucose or starch were used as substrates. Under optimal conditions, the doubling time is $\mathbf{4 8} \mathbf{m i n}$. Sodium ions are necessary for growth, with an optimal concentration of $230 \mathrm{mM}(1 \% \mathrm{NaCl}$, w/v) at pH 9.5. The rod-shaped cells are motile in the exponential growth phase under optimal growth conditions. Despite the Gram-negative staining and negative KOH assay, the strain is a Gram-positive organism, having an atypically thin cell wall. A sheath-like structure occurs at the cell separation area and parts of a surface layer-like structure were also observed. Based on physiological properties and molecular biological analysis, the strain falls within the radiation of the clostridia and represents a new species of Anaerobranca within the Clostridium/Bacillus subphylum of the Gram-positive bacteria. Strain LBS3 $^{\top}$ ( = DSM 13577') is named Anaerobranca gottschalkii sp. nov. and is designated as the type strain.

Keywords: Anaerobranca gottschalkii sp. nov., alkaliphile, thermophile, extremophile

\section{INTRODUCTION}

Alkaliphilic prokaryotes have been isolated from a variety of habitats such as soils, sewage plants and seawater (Grant \& Tindall, 1980; Horikoshi, 1991a; Maeda \& Taga, 1980). A relatively restricted range of mesophilic prokaryotes, mainly representing species of Bacillus, have been investigated intensively and reclassified taxonomically (Fritze et al., 1990; Nielsen et $a l .$, 1995). True alkaline environments are only present at special locations distributed over the world (Grant $\&$ Horikoshi, 1992). Such sites represent habitats for a

† Present address: Biotex, Center for Biotechnology of Extremophiles, Nartenstrasse 4A, D-21079 Hamburg, Germany.

The GenBank accession number for the complete $16 \mathrm{~S}$ rDNA sequence of strain LBS3 ${ }^{\top}$ is AF203703. highly diversified microbial community (Jones et al., 1998). The Great Rift Valley soda lakes are geologically and geochemically well examined (Engle et al., 1995; Grant et al., 1990; Jones et al., 1998), including the low-saline northern lakes (Bogoria, Nakuru, Elmenteita, Sonachi) and the arid, carbonatesaturated southern lakes (Magadi, Natron). Of special interest are the sites in and around Lake Bogoria, the origin of our samples, where a number of hot springs are found with temperatures of up to $96{ }^{\circ} \mathrm{C}$.

Recent studies have shown that the phylogenetic diversity in these lakes is high (Duckworth et al., 1996; Jones et al., 1998). However, only one anaerobic, thermophilic strain growing at $\mathrm{pH} 9.5$ and $70^{\circ} \mathrm{C}$, belonging to the order Thermotogales, 'Thermopallium natronophilum', has been detected. The following isolates are the only identified anaerobic isolates to 
date: Clostridium paradoxum (Li et al., 1993), Clostridium thermoalcaliphilum (Li et al., 1994), Thermococcus alcaliphilus (Keller et al., 1995), Anaerobranca horikoshii (Engle et al., 1995) and one mesophile, Spirochaeta asiatica (Zhilina et al., 1996). Some new, less-halotolerant mesophilic isolates and a few haloalkaliphilic strains have been described (Jones et al., 1998). Based on genetic techniques, however, there is further evidence for the existence of a wide range of strictly anaerobic micro-organisms (Grant et al., 1990; Zhilina \& Zavarzin, 1994). The newly described genus Anaerobranca comprises only one species to date, $A$. horikoshii (Engle et al., 1995). The common features of this genus were described as the formation of branched-type cells, obligately anaerobic, heterotrophic and proteolytic growth and a low DNA G + C content of 30-34 mol\%. Here we describe a new species within this genus.

There is great interest in understanding the mechanisms that allow growth of micro-organisms at high $\mathrm{pH}$ and temperature. In this report, we describe the isolation, characterization and identification of a new anaerobic thermoalkaliphile, $\mathrm{LBS}^{\mathrm{T}}$, isolated from a hot alkaline inlet from the alkaline Lake Bogoria, Kenya. Previously, we reported on the role of sodium ions in the process of energy transduction in this extremophile (Prowe et al., 1996).

\section{METHODS}

Sample collection. Soil samples from Lake Bogoria in Kenya were collected in 1992 from the shore of the lake and from the inlet of a hot spring. The temperatures of the sample sites ranged from 50 to $80^{\circ} \mathrm{C}$ and the $\mathrm{pH}$ was around 9-10. The samples were kept at ambient temperature until inoculation in the laboratory.

Media and culture conditions. Hungate anaerobic technique (Hungate, 1969; Macy et al., 1972) was used to isolate and cultivate strain $\mathrm{LBS}^{\mathrm{T}}$. Isolation was done on a medium containing $\left(\mathrm{g} \mathrm{l}^{-1}\right): \quad\left(\mathrm{NH}_{4}\right)_{2} \mathrm{SO}_{4}, 1 \cdot 5 ; \quad \mathrm{K}_{2} \mathrm{HPO}_{4}, \quad 0 \cdot 5$; $\mathrm{MgSO}_{4} .7 \mathrm{H}_{2} \mathrm{O}, 0 \cdot 1 ; \mathrm{CaCl}_{2} .2 \mathrm{H}_{2} \mathrm{O}, 0.05 ; \mathrm{NaCl}, 3 \cdot 0$; tryptone, 1.0 ; yeast extract, $1.0 ; \mathrm{FeCl}_{3}, 0.01$; resazurin, 0.001 ; trace element solution 141 (DSMZ), $10 \mathrm{ml}$; vitamin solution 141 (DSMZ), $10 \mathrm{ml} ; \mathrm{NaHCO}_{3}, 2 \cdot 2 ; \mathrm{Na}_{2} \mathrm{CO}_{3}, 2 \cdot 2$; cysteine hydrochloride, 0.5 ; with $0.5 \%$ (w/v) starch (Merck) or xylan (Roth) as a carbon source. The medium without carbonates and cysteine was boiled, concentrated to $90 \%$ of the original volume and cooled to $4{ }^{\circ} \mathrm{C}$ under continuous gassing with $\mathrm{O}_{2}$-free $\mathrm{N}_{2}$. Cysteine was added prior to distribution in $15 \mathrm{ml}$ Hungate tubes $(9 \mathrm{ml}$ medium per tube) or $100 \mathrm{ml}$ serum bottles ( 20 or $50 \mathrm{ml}$ per bottle). The sealed tubes were subsequently autoclaved. The carbonate stock solution was concentrated 10-fold and sterilized separately. One millilitre of the carbonate solution was added aseptically to $9 \mathrm{ml}$ sterile medium prior to incubation; the final $\mathrm{pH}$ was $\mathrm{pH} 9 \cdot 5$. Higher or lower $\mathrm{pH}$ values were obtained by varying the concentration of stock carbonate solution.

Cultivation of strain $\mathrm{LBS}^{\mathrm{T}}$ was performed in optimized medium containing (g l $\left.1^{-1}\right)$ : $\left(\mathrm{NH}_{4}\right)_{2} \mathrm{SO}_{4}, 1 \cdot 0 ; \mathrm{NH}_{4} \mathrm{Cl}$, $0.4 ; \quad \mathrm{Na}_{2} \mathrm{~S}_{2} \mathrm{O}_{3}, 0 \cdot 1 ; \mathrm{K}_{2} \mathrm{HPO}_{4}, 0.5 ; \quad \mathrm{MgSO}_{4} .7 \mathrm{H}_{2} \mathrm{O}, 0 \cdot 1$; $\mathrm{CaCl}_{2} \cdot 2 \mathrm{H}_{2} \mathrm{O}, 0 \cdot 05 ; \mathrm{NaCl}, 10 \cdot 0$; tryptone, $0 \cdot 25$; yeast extract, $0.25 ; \mathrm{FeCl}_{3}, 0.01$; resazurin, 0.001 ; trace element solution
141 (DSMZ), $10 \mathrm{ml}$; vitamin solution 141 (DSMZ), $10 \mathrm{ml}$; $\mathrm{NaHCO}_{3}, 2 \cdot 2 ; \mathrm{Na}_{2} \mathrm{CO}_{3}, 2 \cdot 2$; cysteine hydrochloride, $0 \cdot 5$. Additional carbon sources $(0.5 \% \mathrm{w} / \mathrm{v})$ were added prior to boiling or added separately after sterilization.

Isolation and purification. Serum bottles containing anaerobic medium at $\mathrm{pH} 8-10$ were inoculated with samples and incubated at temperatures from 50 to $70^{\circ} \mathrm{C}$. Starch, glucose, peptone or xylan (each $0.5 \% \mathrm{w} / \mathrm{v}$ ) were added as carbon sources. After growth was observed, samples of the culture were plated on solidified medium $\left(15 \mathrm{~g}_{\text {agar }}{ }^{-1}\right)$ in an anaerobic chamber (Microflow Anaerobic System) under a $\mathrm{N}_{2} / \mathrm{H}_{2}(95: 5)$ atmosphere and incubated at $50^{\circ} \mathrm{C}$ in an anaerobic jar for $4 \mathrm{~d}$. Single colonies were picked and again spread on agar-solidified medium until one colony type was observed. The cultures were checked routinely for purity every 2 months. Due to media turbidity caused by different carbon sources, the cell number was determined by counting the cells in a Neubauer counting chamber in order to use a comparable standard method for growth control.

Growth conditions. The influence of temperature on growth was studied by incubation of inoculated media $(5 \%, \mathrm{v} / \mathrm{v})$ containing starch or peptone as carbon source at temperatures between 30 and $70{ }^{\circ} \mathrm{C}$ for $24 \mathrm{~h}$. The cell number was counted every $2 \mathrm{~h}$ in a Neubauer counting chamber. The influence of $\mathrm{pH}$ on growth was studied in media with $\mathrm{pH}$ values varying from 5 to 11 . For $\mathrm{pH} 5 \cdot 0-7 \cdot 5$, the $\mathrm{pH}$ was adjusted by the addition of $1 \mathrm{M} \mathrm{KOH}$ or $1 \mathrm{M} \mathrm{HCl}$ after adding $1 \mathrm{~g} \mathrm{NaHCO}_{3} \mathrm{I}^{-1}$. For $\mathrm{pH} 8 \cdot 0-11 \cdot 0$, different amounts of carbonate were used. During growth at $50{ }^{\circ} \mathrm{C}$, the $\mathrm{pH}$ was adjusted by the addition of sterile $1 \mathrm{M} \mathrm{NaOH}$.

In order to test for aerobic growth, the medium, which contained starch or glucose as the carbon source at $\mathrm{pH} 9 \cdot 5$, was prepared aerobically without the addition of reducing agent and placed in Erlenmeyer shake flasks. In addition, anaerobically prepared media in Hungate tubes, containing starch or glucose as carbon source, were flushed aseptically with air until the resazurin red colour was stable, indicating aerobic conditions. Culture flasks or Hungate tubes were incubated at $50{ }^{\circ} \mathrm{C}$ without shaking.

In all studies concerning the growth conditions ( $\mathrm{pH}$, temperature, substrates, salt), the cell number of a third inoculum was counted after two transfers of culture material under the same conditions.

Substrate spectrum. Growth of strain $\mathrm{LBS}^{\mathrm{T}}$ was tested on different substrates as the sole carbon source by transferring the strain three times to medium containing $0.5 \%(\mathrm{w} / \mathrm{v})$ arabinose, glucose, fructose, galactose, mannose, ribose, xylose, cellobiose, lactose, maltose, sucrose, sorbitol, glycerol, pyruvate, succinate, urea, Tween 80 , casein, peptone, tryptone, yeast extract, starch, xylan, pullulan or cellulose (filter paper) and subsequent counting of the cell number after 6, 12 and $24 \mathrm{~h}$.

Dissimilatory sulfate reduction. Hungate tubes were prepared with the above-described medium, $\mathrm{pH} 9 \cdot 5$, without $\mathrm{Na}_{2} \mathrm{~S}_{2} \mathrm{O}_{3}$ and containing $\mathrm{NH}_{4} \mathrm{Cl}$ instead of $\left(\mathrm{NH}_{4}\right)_{2} \mathrm{SO}_{4}$. In addition, $1 \%(\mathrm{w} / \mathrm{v})$ glucose, $0.02 \%(\mathrm{w} / \mathrm{v})$ lactate or $0.02 \%$ (w/v) pyruvate, supplemented with $0.01 \%$ (w/v) $\mathrm{FeSO}_{4}$, $0 \cdot 1 \%(\mathrm{w} / \mathrm{v}) \mathrm{Na}_{2} \mathrm{~S}_{2} \mathrm{O}_{3}$ or $0 \cdot 1 \% \mathrm{Na}_{2} \mathrm{SO}_{4}$, was added. Medium containing additional elemental sulfur was supplemented with either glucose at $1 \%(\mathrm{w} / \mathrm{v})$, pyruvate at $0.02 \%(\mathrm{w} / \mathrm{v})$ or lactate $(0.02 \% \mathrm{w} / \mathrm{v})$. In addition, the medium containing sulfur was flushed anaerobically with $\mathrm{H}_{2}$ in the presence of glucose as carbon source. Production of sulfide was 
visualized by the addition of $\mathrm{FeSO}_{4}$ or $\mathrm{CuSO}_{4}$ (from a stock solution of $0.6 \% \mathrm{w} / \mathrm{v}$ ) resulting in a blackening of the medium (modified method of Smibert \& Krieg, 1994).

Cellular characterization. Gram staining of strain $\mathrm{LBS}^{\mathrm{T}}$ was determined by staining cells using the Hucker method (in Gerhardt et al., 1994) and KOH lysis (Buck, 1982), using cells from 4 and $20 \mathrm{~h}$ cultures. For the sporulation test, cells were grown for up to $7 \mathrm{~d}$ in a medium containing $0.5 \%(\mathrm{w} / \mathrm{v})$ glucose as carbon source. The presence of spores was determined by phase-contrast microscopy (Zeiss Axioplan).

Scanning electron microscopy of whole cells was performed with a Leitz ISI-SR-50 scanning electron microscope. Cell material from a $50 \mathrm{ml}$ culture grown for $8 \mathrm{~h}$ was prepared according to Lamed et al. (1987) without ferritin.

Transmission electron microscopy was performed in a Phillips EM 01 at $80 \mathrm{kV}$. For ultrathin sections, cells were treated according to Behn \& Arnold (1974). Cell material was harvested from a $50 \mathrm{ml}$ culture grown for $8 \mathrm{~h}$ and washed twice with a $100 \mathrm{mM}$ PBS buffer pH $8.0\left(\mathrm{~K}_{2} \mathrm{HPO}_{4}\right.$, $8.7 \mathrm{~g} \mathrm{l}^{-1} ; \mathrm{KH}_{2} \mathrm{PO}_{4}, 6.8 \mathrm{~g} \mathrm{l}^{-1} ; \mathrm{NaCl}, 9.0 \mathrm{~g} \mathrm{l}^{-1}$; glycine, $0.75 \mathrm{~g}$ $\left.1^{-1}\right)$. Embedding was done by the method of Spurr (1969) and polymerization was performed for $8 \mathrm{~h}$ at $70{ }^{\circ} \mathrm{C}$. Ultrathin sectioning and contrasting with lead-citrate solution was performed as described previously (Venable \& Coggeshall, 1965). Negative staining was performed according to Valentine et al. (1968).

Salt tolerance. Salt concentrations $(\mathrm{NaCl}$ or $\mathrm{KCl})$ were varied between 0 and $5 \%(855 \mathrm{mM})$ in a medium containing $0.5 \%(\mathrm{w} / \mathrm{v})$ starch. Growth was followed at optimal $\mathrm{pH}$ by counting the cell number every $2 \mathrm{~h}$.

Antibiotic resistance. Antibiotics were prepared as concentrated stock solutions, filter-sterilized and added to a freshly $10 \%(\mathrm{v} / \mathrm{v})$ inoculated liquid medium at $\mathrm{pH} 8.0$; the lower $\mathrm{pH}$ was chosen in order to prevent inactivation of antibiotics

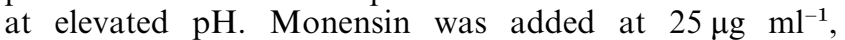
rifampicin at $50 \mu \mathrm{g} \mathrm{ml} l^{-1}$, nalidixic acid at $50 \mu \mathrm{g} \mathrm{ml} l^{-1}$, chloramphenicol at $25 \mu \mathrm{g} \mathrm{ml}^{-1}$, penicillin at 25 and $100 \mu \mathrm{g}$ $\mathrm{ml}^{-1}$ and streptomycin at 25 and $250 \mu \mathrm{g} \mathrm{ml}^{-1}$. Cultures were incubated at $50{ }^{\circ} \mathrm{C}$ for $24 \mathrm{~h}$.

Fermentation products. Analysis of fermentation products was performed by HPLC (Knauer) using a Bio-Rad HPX-87 $\mathrm{H}$ column with $5 \mathrm{mM} \mathrm{H}_{2} \mathrm{SO}_{4}$ as the liquid phase.

16S rDNA sequence analysis. DNA analysis was performed at the DSMZ. Genomic DNA extraction from lyophilized cell mass, PCR-mediated amplification of the 16S rDNA and purification of PCR products were carried out as described previously (Rainey et al., 1992; Rainey \& Stackebrandt, 1993). The $16 \mathrm{~S}$ rDNA sequence data were compared with all currently available sequences of organisms belonging to the Clostridium/Bacillus subphylum of the Gram-positive bacteria. Pairwise evolutionary distances (Jukes \& Cantor, 1969) and the least-squares distance method of De Soete (1983) were used in the construction of the phylogenetic dendrogram from distance matrices.

DNA isolation, DNA-DNA hybridization and determination of $\mathbf{G}+\mathbf{C}$ content. DNA from the new strain $\mathrm{LBS}^{\mathrm{T}}$ and $A$. horikoshii was isolated by chromatography on hydroxyapatite by the procedure of Cashion et al. (1977). DNADNA hybridization and computation were carried out at the DSMZ using the methods of De Ley et al. (1970) and Jahnke (1992), with the modification described (Escara \& Hutton, 1980; Huss et al., 1983).
DNA for the determination of $\mathrm{G}+\mathrm{C}$ content was isolated as described above. The DNA was digested enzymically and the $\mathrm{G}+\mathrm{C}$ content was determined by HPLC by separating the nucleotides as described by Mesbah et al. (1989).

Analysis of lipid components. Analysis of the respiratory lipoquinone, fatty acids and the polar lipid pattern of $\mathrm{LBS}^{\mathrm{T}}$ and $A$. horikoshii were carried out by B. J. Tindall (DSMZ, Braunschweig, Germany) using methods described previously (Tindall, 1990a, b).

\section{RESULTS AND DISCUSSION}

\section{Isolation of thermoalkaliphilic bacteria}

Enrichment cultures ( $\mathrm{pH} 9 \cdot 0$ ) containing starch or glucose and inoculated with sample material from a hot lake inlet of Lake Bogoria showed bacterial growth after $24 \mathrm{~h}$ of anaerobic incubation at $50{ }^{\circ} \mathrm{C}$. Microscopy revealed the presence of rod-shaped cells (Fig. 1) that all seemed to belong to the same phenotype. After incubation for $24 \mathrm{~h}$ under anaerobic conditions, culture material was plated on an agar-solidified medium containing $0.5 \%(\mathrm{w} / \mathrm{v})$ starch. After a number of transfers, uniform small, pale-whitish, lens-shaped colonies with smooth edges and diameters of 3-5 mm were observed. These colonies and the resulting liquid cultures were shown to exhibit the same characteristics. One culture, strain $\mathrm{LBS3}^{\mathrm{T}}$, was selected as the culture for the type strain.

\section{Cellular characteristics}

Cells of strain LBS3 ${ }^{\mathrm{T}}$ (Anaerobranca gottschalkii) from the exponential phase were rod-shaped $(0 \cdot 3-0.5 \mu \mathrm{m}$ wide and $2-3 \mu \mathrm{m}$ long). They occurred singly or as short chains of up to four cells. Using glucose as substrate, the cells were motile, especially in the early exponential growth phase around the $\mathrm{pH}$ optimum of pH 9.5 (see Fig. 3a). Morphological changes were observed in the stationary growth phase. Protoplastlike structures and pleiomorphic, irregular cell chains were observed after 24 and $48 \mathrm{~h}$. Cells from the late

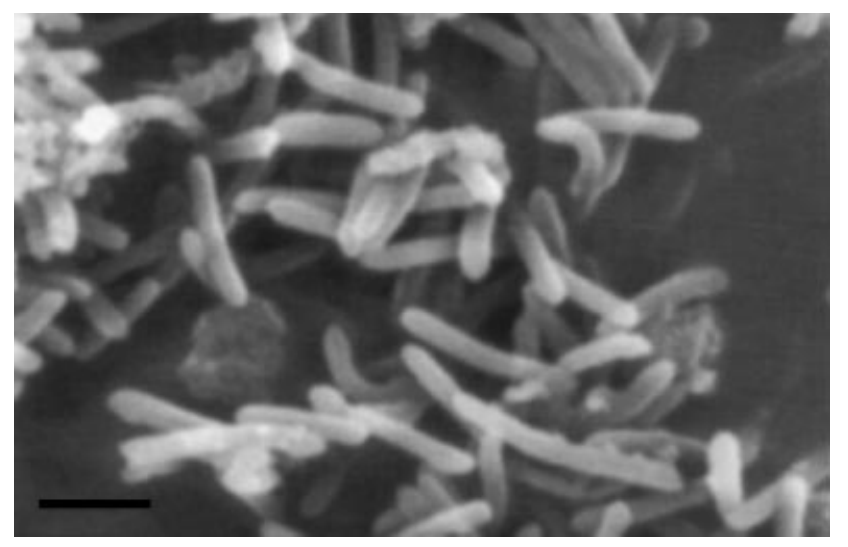

Fig. 1. Scanning electron micrograph of cells of $A$. gottschalkii LBS3 $^{\top}$. Bar, $1 \cdot 4 \mu \mathrm{m}$. 

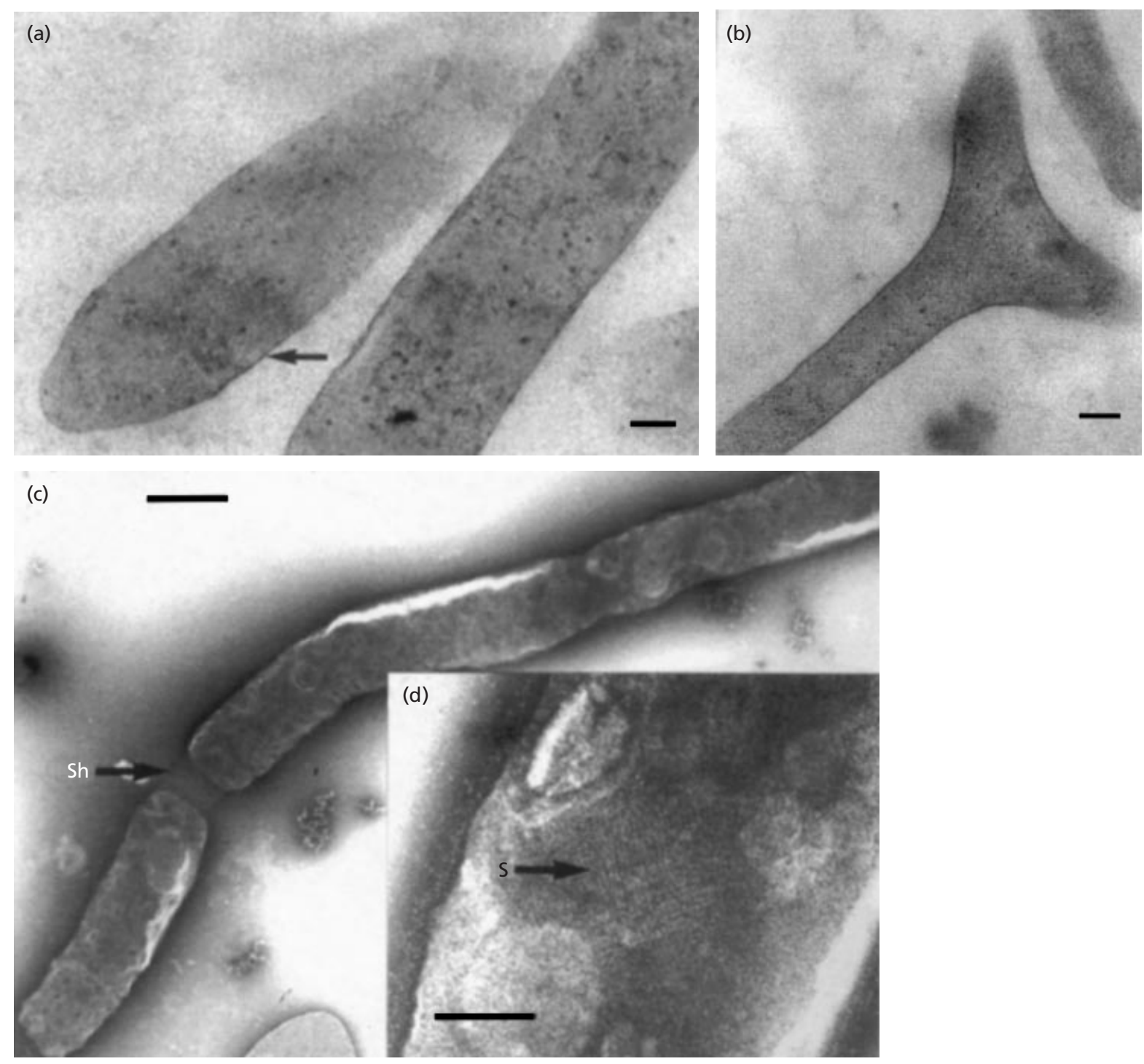

Fig. 2. (a)-(b) Electron micrographs of ultrathin-sectioned cells of $A$. gottschalkii $\mathrm{LBS}^{\top}$ from the exponential growth phase showing the atypically thin cell wall (a) (indicated by arrow) and branch formation (b); no separation was found at the branch junction. (c)-(d) Electron micrographs of negatively contrasted cells of $A$. gottschalkii LBS3 ${ }^{\top}$ showing the sheath-like structure (Sh) at the separation area (c) and part of a surface layer-like structure (S) (d). Bars, 0.1 $\mu \mathrm{m}(\mathrm{a}, \mathrm{d})$ and $0.3 \mu \mathrm{m}(\mathrm{b}, \mathrm{c})$.

phase of growth were less motile. In addition, a few Ytype branched cells were also observed (Fig. 2b). The ultrathin sections shown in Fig. 2(b) indicate that these forms consisted of only one cell. Similar cell morphology of primary branched cells was reported for the alkalitolerant thermophilic bacterium A. horikoshii (Engle et al., 1995). The KOH assay and Gram staining of cells of $A$. gottschalkii $\mathrm{LBS}^{\mathrm{T}}$ were negative, regardless of the age of the culture. This property, which was also observed for the thermoalkaliphiles Clostridium paradoxum ( $\mathrm{Li}$ et al., 1993) and Clostridium thermoalcaliphilum (Li et al., 1994), seems to be widespread in Gram-positive alkaliphiles (Grant \& Horikoshi, 1992). A. horikoshii, on the other hand, showed a positive Gram stain and a typical Gram- positive-type cell wall in ultrathin sections (Engle et al., 1995), which allowed distinction of the strain from $A$. gottschalkii LBS3 ${ }^{\mathrm{T}}$. A. gottschalkii $\mathrm{LBS}^{\mathrm{T}}$ is, nevertheless, regarded as Gram-positive, due to the data obtained from 16S rDNA analysis (see below). This was also supported by the fact that protoplasts were obtained easily by lysozyme treatment (Prowe et al., 1996). Ultrathin sectioning of cells also showed an atypical thin cell wall (Fig. 2a), as reported already for Clostridium paradoxum (Li et al., 1993). Negativecontrast electron microscopy of whole cells showed the presence of a sheath-like structure around the cells (Fig. 2c, d). The presence of an outer surface layer has been reported for alkaliphilic Bacillus species (Krulwich, 1982) and a sheath-like structure was 

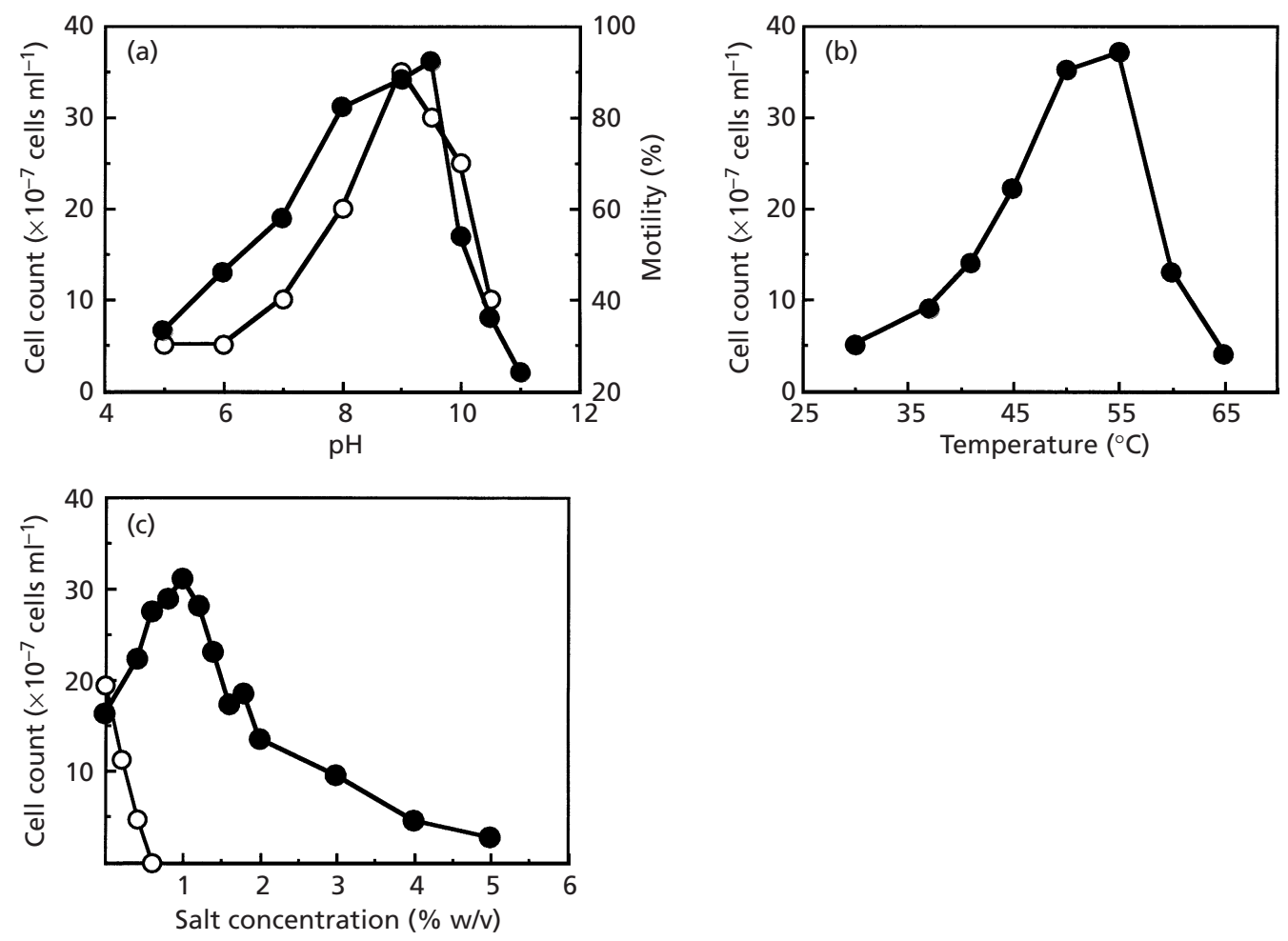

Fig. 3. (a) Effect of $\mathrm{pH}$ on growth (O) and motility (O) of $A$. gottschalkii LBS3 ${ }^{\top}$. Incubation was at $50{ }^{\circ} \mathrm{C}$ in the medium described containing starch $(0.5 \% \mathrm{w} / \mathrm{v})$ or peptone $(1 \% \mathrm{w} / \mathrm{v})$. Results were similar regardless of the substrate used. (b) Effect of temperature on growth of $A$. gottschalkii $\mathrm{LBS}^{\mathrm{T}}$. The curve was obtained by cultivation of the strain for up to $24 \mathrm{~h}$ in a medium containing starch $(0.5 \% \mathrm{w} / \mathrm{v})$ or peptone $(1 \% \mathrm{w} / \mathrm{v}), \mathrm{pH} 9.5$. Results were similar independent of the substrate used. (c) Effect of various salt concentrations on growth of $A$. gottschalkii LBS3 ${ }^{\top}$. The medium at pH 9.5, supplemented with $0.5 \%(\mathrm{w} / \mathrm{v})$ starch, contained additional amounts of $\mathrm{NaCl}(\mathbf{O})$ or $\mathrm{KCl}(\mathrm{O})$. Incubation was performed at $50^{\circ} \mathrm{C}$ for $12 \mathrm{~h}$.

observed in Clostridium thermoalcaliphilum (Li et al., 1994).

A. gottschalkii $\mathrm{LBS}^{\mathrm{T}}$ did not grow on solid or liquid medium supplemented with $\mathrm{MnSO}_{4}$. Endospores were not observed either in fresh cultures or in old cultures stored at $4{ }^{\circ} \mathrm{C}$ or those kept at room temperature for months. Such stored cultures lost their viability after 4 weeks, indicating the absence of spores. Cultures incubated at $50{ }^{\circ} \mathrm{C}$ for $8 \mathrm{~h}$ at $\mathrm{pH} 9.5$ were not resistant to heat $\left(80\right.$ or $90{ }^{\circ} \mathrm{C}$ for $\left.5-10 \mathrm{~min}\right)$. No growth was observed after inoculation of these cells into fresh medium, thus indicating the absence of heat-resistant spores. Similar observations were made for the nonspore-forming Clostridium thermoalcaliphilum (Li et al., 1994).

\section{Growth conditions}

No growth was observed under aerobic conditions, with starch or glucose as substrate. Growth occurred only anaerobically between $\mathrm{pH} 6.0$ and $10 \cdot 5$, with an optimum $\mathrm{pH}$ for growth at 9.5 (Fig. 3a) when incubated at $50{ }^{\circ} \mathrm{C}$ with starch or glucose as carbon source. The largest number of motile cells was observed around the optimal pH (Fig. 3a). Since the strain was also able to grow at neutral $\mathrm{pH}$, it should be considered as a facultative alkaliphile, according to a proposed definition (Grant \& Horikoshi, 1992; Horikoshi, 1991a; Krulwich \& Guffanti, 1989).

In experiments performed in $\mathrm{pH}$-controlled fermentations with starch or peptone as energy sources, $A$. gottschalkii $\mathrm{LBS}^{\mathrm{T}}$ exhibited a doubling time of $48 \mathrm{~min}$ at $\mathrm{pH} 9.5$ and $50{ }^{\circ} \mathrm{C}$. At $\mathrm{pH} 10$, the doubling time increased to $100 \mathrm{~min}$.

The temperature range for growth was $30-65^{\circ} \mathrm{C}$ with an optimum temperature for growth of $50-55^{\circ} \mathrm{C}$ (Fig. $3 b)$. Cells grown at temperatures below $40{ }^{\circ} \mathrm{C}$ or above $60{ }^{\circ} \mathrm{C}$ were pleiomorphic and did not correspond to the shape of cells grown at optimum temperatures. Thus, A. gottschalkii $\mathrm{LBS}^{\mathrm{T}}$ is regarded as a moderately thermophilic micro-organism.

\section{Salt tolerance}

The effect of $\mathrm{NaCl}$ under optimal growth conditions $\left(\mathrm{pH} 9 \cdot 5,50{ }^{\circ} \mathrm{C}\right)$ showed a concentration range for growth of $0-4 \%(\mathrm{w} / \mathrm{v})$, with an optimum concentration of $1 \% \mathrm{NaCl}(\mathrm{w} / \mathrm{v})$ (Fig. 3c). The tolerated $\mathrm{Na}^{+}$ concentration is therefore $60-560 \mathrm{mM}$. The amount of $\mathrm{Na}^{+}$resulting from sodium carbonates $\left(2 \cdot 2 \mathrm{~g} \mathrm{l}^{-1}\right)$ at pH 9.5 is $60 \mathrm{mM}$. Accordingly, the $\mathrm{Na}^{+}$concentration for optimal growth at $1 \% \mathrm{NaCl}$ is $230 \mathrm{mM}$. These data 
differ from the concentrations tolerated by Clostridium paradoxum (Li et al., 1993) and Clostridium thermoalcaliphilum ( $\mathrm{Li}$ et al., 1994), where $\mathrm{Na}^{+}$concentrations of $750 \mathrm{mM}$ and $1.25 \mathrm{M}$, respectively, were tolerated. The optimal concentration of $\mathrm{Na}^{+}$ions for Clostridium paradoxum and Clostridium thermoalcaliphilum is 50$100 \mathrm{mM}$ and that for Clostridium thermoalcaliphilum is $200 \mathrm{mM}$ in the presence of $\mathrm{K}^{+}$ions. These values are lower than those obtained for $A$. gottschalkii $\mathrm{LBS}^{\mathrm{T}}$. In the case of $A$. gottschalkii $\mathrm{LBS}^{\mathrm{T}}, \mathrm{Na}^{+}$could not be replaced by $\mathrm{K}^{+}$, resulting in a dramatic decrease of the growth yield at $\mathrm{K}^{+}$concentrations above $27 \mathrm{mM}$ $(0 \cdot 2 \% \mathrm{w} / \mathrm{v} \mathrm{KCl})$ (Fig. 3c). As reported previously, $\mathrm{Na}^{+}$ ions play a major role in the energy transduction of this micro-organism; $\mathrm{K}^{+}$ions have no such effect (Prowe et al., 1996). Based on these results, it can be concluded that $A$. gottschalkii $\mathrm{LBS}^{\mathrm{T}}$ depends strictly on $\mathrm{Na}^{+}$ions for growth.

The fact that alkaliphiles require $\mathrm{Na}^{+}$for their growth is well documented in earlier reports (Duckworth et al., 1996; Horikoshi, 1991a, b; Li et al., 1993, 1994; Zhilina \& Zavarzin, 1994; Zhilina et al., 1996). Most of the environments of alkaliphilic micro-organisms have high $\mathrm{Na}^{+}$concentrations. The function of this ion in neutrophiles (Lolkema et al., 1994), as well as alkaliphiles (Krulwich \& Guffanti, 1989; Krulwich et al., 1990) and some extremophiles (Speelmans et al., 1995), is either as a coupling ion for energy transduction or in $\mathrm{pH}$ homeostasis. We have demonstrated previously that $\mathrm{Na}^{+}$ions play a crucial role in the energy transduction of strain $\mathrm{LBS}^{\mathrm{T}}$ (Prowe et al., 1996). This was also supported by the fact that $\mathrm{Na}^{+}$ could not be replaced by $\mathrm{K}^{+}$in the growth medium.

\section{Substrates and fermentation products}

A. gottschalkii $\mathrm{LBS}^{\mathrm{T}}$ grew on a variety of substrates including carbohydrates, proteins and peptides. The addition of $0 \cdot 1 \mathrm{~g}$ yeast extract and $0.1 \mathrm{~g}$ tryptone $1^{-1}$ was required for optimal growth. In their absence, changes in cellular morphology were observed. Good growth with cell densities of up to $5 \times 10^{8}$ cells $\mathrm{ml}^{-1}$ was observed in batch cultures (serum bottles) without stirring in the presence of $0.5 \%(\mathrm{w} / \mathrm{v})$ glucose, fructose, mannose, maltose, sucrose, peptone, tryptone or yeast extract. Starch and pullulan were also hydrolysed. Growth $\left(1 \times 10^{8}\right.$ cells $\left.\mathrm{ml}^{-1}\right)$ was observed with ribose, casein, xylan and cellulose (filter paper). Moderate growth $\left(5 \times 10^{7}\right.$ cells $\left.\mathrm{ml}^{-1}\right)$ was obtained with galactose, xylose, cellobiose, lactose and glycerol $(0.5 \% \mathrm{w} / \mathrm{v}$ each). The main fermentation product during growth on starch or glucose at $\mathrm{pH} 9 \cdot 5$ was acetate; small amounts of ethanol $\left(<1 \mu \mathrm{mol} \mathrm{m}^{-1}\right)$ were also detected. Gaseous products were not detected by HPLC.

\section{Dissimilatory sulfate reduction}

Compared with a control (without additional $\mathrm{Na}_{2} \mathrm{~S}_{2} \mathrm{O}_{3}$ ), growth of $A$. gottschalkii $\mathrm{LBS}^{\mathrm{T}}$ on glucose or starch was enhanced in the presence of $\mathrm{Na}_{2} \mathrm{~S}_{2} \mathrm{O}_{3}$
Table 1 Susceptibility of $A$. gottschalkii $\mathrm{LBS}^{\top}$ to antibiotics

Growth conditions were $50{ }^{\circ} \mathrm{C}$ and $\mathrm{pH} 9 \cdot 0$. Cells were grown without antibiotics for one generation and then inoculated to a medium preincubated with the drug at the concentrations shown. Growth inhibition is scored as: + , inhibition of growth; -, no inhibition of growth.

\begin{tabular}{|lcc|}
\hline Antibiotic & $\begin{array}{c}\text { Concentration } \\
\left(\boldsymbol{\mu} \mathbf{~ m ~}^{-\mathbf{1}}\right)\end{array}$ & $\begin{array}{c}\text { Inhibition of } \\
\text { growth }\end{array}$ \\
\hline Chloramphenicol & 25 & + \\
Monensin & 25 & + \\
Rifampicin & 50 & - \\
Nalidixic acid & 50 & + \\
Penicillin & 25 & - \\
& 100 & - \\
Streptomycin & 25 & + \\
& 250 & \\
\hline
\end{tabular}

$(0.01 \% \mathrm{w} / \mathrm{v})$. Good growth of $A$. gottschalkii LBS3 ${ }^{\mathrm{T}}$ $\left(1 \times 10^{9}\right.$ cells $\left.\mathrm{ml}^{-1}\right)$ was also observed when elemental sulfur was used. Thus, sulfur does not inhibit growth. Under these conditions, elemental sulfur was partially solubilized, resulting in a yellow-coloured medium, which may be due to the formation of polysulfide at $\mathrm{pH}$ 9.5. During growth in the presence of sulfurcontaining compounds $\left(\mathrm{Na}_{2} \mathrm{~S}_{2} \mathrm{O}_{3}\right.$ and $\left.\mathrm{S}^{0}\right), \mathrm{H}_{2} \mathrm{~S}$ was detected by the addition of $\mathrm{FeSO}_{4}$ or $\mathrm{CuSO}_{4}$, resulting in a deep blackening of the medium due to the precipitation of $\mathrm{FeS}$ or $\mathrm{CuS}$; the controls did not show this effect. Growth on sulfur with glucose as carbon source was inhibited when the medium was gassed with $\mathrm{H}_{2}$ prior to inoculation. Thus, it is suggested that thiosulfate can be used as electron acceptor. This was also reported for members of the order Thermotogales (Ravot et al., 1995) when glucose or other fermentable carbohydrates were used for growth. The addition of $\mathrm{Na}_{2} \mathrm{SO}_{4}$ or $\mathrm{FeSO}_{4}$ did not stimulate or inhibit growth. No dissimilatory sulfate reduction was detected, excluding the organism from the genus Desulfotomaculum.

\section{Sensitivity to antibiotics}

As shown in Table 1, inhibition of growth was observed with chloramphenicol, monensin and nalidixic acid. No inhibition was observed with rifampicin or penicillin. Streptomycin showed an inhibitory effect at higher concentrations only. This is in agreement with the bacterial sensitivity pattern towards antibiotics.

\section{Phylogenetic position}

A complete sequence (1433 bases) of the 16S rDNA of strain $A$. gottschalkii $\mathrm{LBS}^{\mathrm{T}}$ was analysed and compared with all currently available sequences of organisms belonging to the Clostridium/Bacillus sub- 


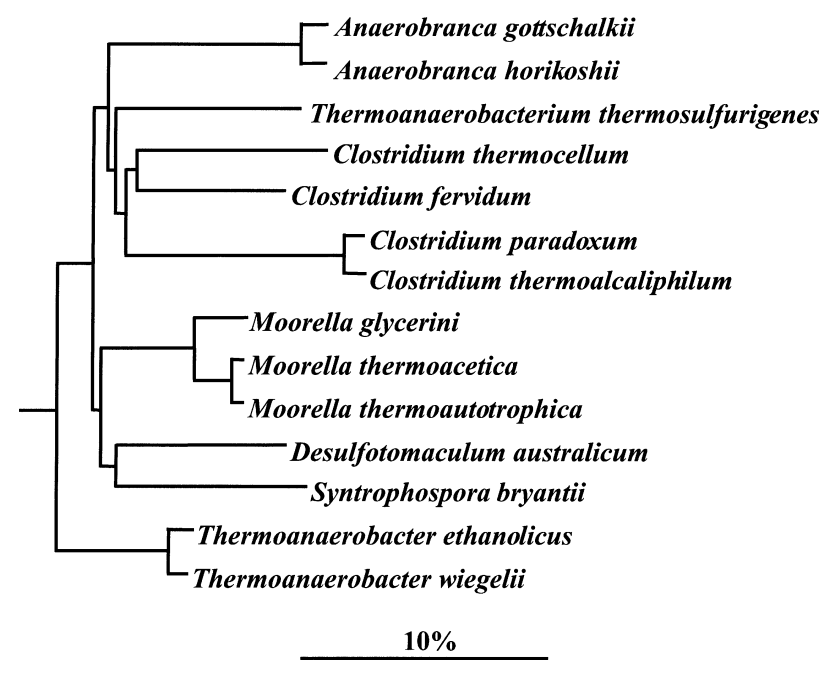

Fig. 4. Phylogenetic tree for A. gottschalkii $\mathrm{LBS}^{\top}$ and related organisms based on results of $16 \mathrm{~S}$ rDNA sequence analysis. Bar, 10 inferred changes per 100 nucleotides.

phylum of the Gram-positive bacteria (Fig. 4). The closest relationship was to $A$. horikoshii, at the level of $97 \cdot 5 \% 16 \mathrm{~S}$ rDNA similarity. The DNA G $+\mathrm{C}$ content of $A$. gottschalkii $\mathrm{LBS}^{\mathrm{T}}$ is $30 \cdot 9 \mathrm{~mol} \%$, which differs from the $\mathrm{G}+\mathrm{C}$ content reported for A. horikoshii $(34.3 \mathrm{~mol} \%)$. DNA-DNA hybridization with $A$. horikoshii showed only $60 \cdot 4 \%$ relatedness. In addition, the lipid composition of the strains also differed. The main fatty acids in the lipids of $A$. horikoshii are 14:0 $(26 \%)$, i-15:0 (7.5\%), 15:0 (11\%) and 16:0 (28\%). The lipids in A. gottschalkii LBS3 ${ }^{\mathrm{T}}$ consist mainly of the fatty acids i-13:0 (4.3\%), i-15:0 (42\%), ai-15:0 $(12 \%)$ and $16: 0(11 \%)$, with smaller amounts of ai$13: 0(2 \cdot 6 \%)$ and ai-17:0 (3.4\%) fatty acids.

These data demonstrate clearly that the new isolate is a new species within the genus Anaerobranca. This fact is also supported by the physiological and morphological data presented in Table 2. In contrast to $A$. horikoshii, the new isolate is able to grow on a variety of complex proteinaceous substrates (yeast extract, peptone, tryptone), sugars and polysaccharides. $A$. horikoshii is only able to utilize a restricted number of substrates for growth. The morphological feature of branched cells was also observed for A. horikoshii (Engle et al., 1995), but the negative Gram-type staining and the thin cell wall of $A$. gottschalkii LBS3 ${ }^{\mathrm{T}}$ reflect the differences between the two species. The ability of $A$. gottschalkii $\mathrm{LBS}^{\mathrm{T}}$ to reduce thiosulfate suggests that these are phylogenetically distinct strains.

Table 2 Characteristics that distinguish A. gottschalkii LBS3 ${ }^{\top}$ from A. horikoshii

Data for A. horikoshii were taken from Engle et al. (1995). Utilization of compounds is scored as: ++ , growth to $2-5 \times 10^{8}$ cells $\mathrm{ml}^{-1} ;+$, growth to $0 \cdot 5-1 \times 10^{8}$ cells $\mathrm{ml}^{-1} ;-$, no growth. Both taxa produce Y-shaped, branched cells and show strong growth $\left(2-5 \times 10^{8}\right.$ cells $\left.\mathrm{ml}^{-1}\right)$ on yeast extract, peptone and tryptone. Neither taxon forms spores. ND, Not determined.

\begin{tabular}{|c|c|c|}
\hline Characteristic & A. gottschalkii $\mathrm{LBS3}^{\mathrm{T}}$ & A. horikoshii \\
\hline DNA G $+\mathrm{C}$ content $(\mathrm{mol} \%)$ & $30 \cdot 9$ & $33-34$ \\
\hline $\mathrm{pH}$ range for growth & $6 \cdot 0-10 \cdot 5$ & $6 \cdot 5-10 \cdot 3$ \\
\hline Optimum $\mathrm{pH}$ for growth & $9 \cdot 5$ & $8 \cdot 5-8 \cdot 8$ \\
\hline Optimum temperature $\left({ }^{\circ} \mathrm{C}\right)$ & $50-55$ & 57 \\
\hline Optimum $\mathrm{Na}^{+}$concentration $(\mathrm{mM})$ & 230 & $8 \cdot 5$ \\
\hline Gram staining & - & + \\
\hline Gram type & $+($ Thin cell wall $)$ & $+($ Thick cell wall $)$ \\
\hline $\mathrm{S}_{2} \mathrm{O}_{3} \rightarrow \mathrm{S}^{2-}$ & $+($ Growth stimulated $)$ & - \\
\hline Fermentation products & Acetate, ethanol & Acetate, $\mathrm{CO}_{2}, \mathrm{H}_{2}$ \\
\hline \multicolumn{3}{|l|}{ Utilization of: } \\
\hline Starch & ++ & - \\
\hline Pullulan & + & ND \\
\hline Xylan & - & ND \\
\hline Cellulose & + & ND \\
\hline Glucose & ++ & - \\
\hline Fructose & ++ & - \\
\hline Mannose & ++ & ND \\
\hline Maltose & ++ & - \\
\hline Sucrose & ++ & - \\
\hline Ribose & + & - \\
\hline Galactose & + & - \\
\hline Cellobiose & + & - \\
\hline Lactose & + & - \\
\hline Glycerol & + & - \\
\hline
\end{tabular}


No observations were reported on the effect of thiosulfate on growth of $A$. horikoshii.

A. gottschalkii $\mathrm{LBS}^{\mathrm{T}}$ exhibits a large evolutionary distance from other thermoalkaliphilic members of the clostridium subphylum. The 16S rDNA similarity values to Clostridium paradoxum (Li et al., 1993) and Clostridium thermoalcaliphilum (Li et al., 1994) are only 83.3 and $83.1 \%$. The distinct differences in their physiological and structural features clearly separate these strains from $A$. gottschalkii $\mathrm{LBS}^{\mathrm{T}}$. Closer similarities were found to two Moorella species, Caloramator fervidus and Clostridium thermocellum (Fig. 4). These bacteria clearly differ from $A$. gottschalkii $\mathrm{LBS}^{\mathrm{T}}$ in their physiological features $(\mathrm{pH}$ and temperature range of growth, substrate utilization) and cellular characteristics $\left(A\right.$. gottschalkii LBS3 $^{\mathrm{T}}$ possesses an atypically thin cell wall, has almost no spore formation and exhibits branched cells) as well as their phylogenetic position (Fig. 4). Thus, strain LBS3 ${ }^{\mathrm{T}}$ is not a member of any previously described species within the Clostridium/Bacillus subphylum. Based on phylogenetic analysis by $16 \mathrm{~S}$ rDNA, DNA-DNA homology and $\mathrm{G}+\mathrm{C}$ content, the strain was found to be closely related to $A$. horikoshii, but represents a new species within the recently described genus Anaerobranca (Engle et al., 1995).

\section{Description of Anaerobranca gottschalkii sp. nov.}

Anaerobranca gottschalkii (gott.schalk'i.i. M.L. gen. n. gottschalkii after Gerhard Gottschalk, in recognition of his pioneering contributions to our knowledge of the physiology and metabolism of anaerobes).

Cells are rod-shaped, Gram-positive, 0.3-0.5 $\mu \mathrm{m}$ thick and $3-5 \mu \mathrm{m}$ long. Colonies are $3-5 \mathrm{~mm}$ in diameter, pale-whitish and lens-shaped. Obligately anaerobic. Temperature range for growth is $30-65^{\circ} \mathrm{C}$, with an optimum around $50-55^{\circ} \mathrm{C}$. Range of $\mathrm{pH}$ for growth is $\mathrm{pH} 6-10 \cdot 5$, with an optimum at $\mathrm{pH} 9 \cdot 5$. Growth from 0 to $4 \% \mathrm{NaCl}(\mathrm{w} / \mathrm{v})$ with an optimum around $1 \%$ $\mathrm{NaCl}$ (w/v; final $\mathrm{Na}^{+}$concentration $230 \mathrm{mM}$ ). Grows heterotrophically with glucose, fructose, mannose, maltose, sucrose, starch, pullulan, peptone, tryptone and yeast extract. Growth is observed in the presence of sulfate, thiosulfate or sulfur. Thiosulfate enhances growth in the presence of glucose and starch, resulting in the formation of $\mathrm{H}_{2} \mathrm{~S}$. Fermentation products (on starch with thiosulfate) are acetate and ethanol. Cell wall is thin, but the strain belongs to the Gram-positive type. Branched cells are regularly present as $2-10 \%$ of the total number of cells.

Strain LBS3 ${ }^{\mathrm{T}}$ ( = DSM $13577^{\mathrm{T}}$ ) is the type strain of $A$. gottschalkii and was isolated from a hot lake inlet at Lake Bogoria, Kenya.

\section{ACKNOWLEDGEMENTS}

This paper is dedicated to Gerhard Gottschalk on the occasion of his 65th birthday. The work performed in the authors' laboratory was supported by the European Com- mission 'Biotechnology of Extremophiles', BIO2-CT 9302734, and 'Die Deutsche Bundesstiftung Umwelt'. We would like to thank the DSMZ for kind support on the classification of the strain and Michael Hoppert (University of Göttingen) for kindly performing the transmission electron microscopy.

\section{REFERENCES}

Behn, W. \& Arnold, C. G. (1974). Die Wirkung von Streptomycin und Neamin auf die Chloroplasten- und Mitochondrienstruktur von Chlamydomonas reinhardtii. Protoplasma 82, 77-89.

Buck, J. D. (1982). Nonstaining (KOH) method for determination of Gram reactions of marine bacteria. Appl Environ Microbiol 44, 992-993.

Cashion, P., Holder-Franklin, M. A., McCully, J. \& Franklin, M. (1977). A rapid method for the base ratio determination of bacterial DNA. Anal Biochem 81, 461-466.

De Ley, J., Cattoir, H. \& Reynaerts, A. (1970). The quantitative measurement of DNA hybridization from renaturation rates. Eur J Biochem 12, 133-142.

De Soete, G. (1983). A least squares algorithm for fitting additive trees to proximity data. Psychometrika 48, 621-626.

Duckworth, A. W, Grant, W. D., Jones, B. E. \& van Steenbergen, R. (1996). Phylogenetic diversity of soda lake alkaliphiles. FEMS Microbiol Ecol 19, 181-191.

Engle, M., Li, Y., Woese, C. \& Wiegel, J. (1995). Isolation and characterization of a novel alkalitolerant thermophile, Anaerobranca horikoshii gen. nov., sp. nov. Int J Syst Bacteriol 45, $454-461$.

Escara, J. F. \& Hutton, J. R. (1980). Thermal stability and renaturation of DNA in dimethyl sulfoxide solutions: acceleration of the renaturation rate. Biopolymers 19, 1315-1327.

Fritze, D., Flossdorf, J. \& Claus, D. (1990). Taxonomy of alkaliphilic Bacillus strains. Int J Syst Bacteriol 40, 92-97.

Gerhardt, P., Murray, R. G. E., Wood, W. A. \& Krieg, N. R. (editors) (1994). Methods for General and Molecular Bacteriology. Washington, DC: American Society for Microbiology.

Grant, W. D. \& Horikoshi, K. (1992). Alkaliphiles: ecology and biotechnological applications. In Molecular Biology and Biotechnology of Extremophiles, pp. 143-162. Edited by R. A. Herbert \& R. J. Sharp. Glasgow: Blackie \& Son.

Grant, W. D. \& Tindall, B. J. (1980). The isolation of alkalophilic bacteria. In Microbial Growth and Survival in Extremes of Environment, pp. 27-36. Edited by G. W. Gould \& J. C. L. Corry. London: Academic Press.

Grant, W. D., Mwatha, W. E. \& Jones, B. E. (1990). Alkaliphiles: ecology, diversity and applications. FEMS Microbiol Rev 75, 255-270.

Horikoshi, K. (1991a). Microorganisms in Alkaline Environments. Weinheim: VCH Verlagsgesellschaft.

Horikoshi, K. (1991b). General view of alkaliphiles and thermophiles. In Superbugs: Microorganisms in Extreme Environments, pp. 3-14. Edited by K. Horikoshi \& W. D. Grant. Berlin: Springer.

Hungate, R. E. (1969). A roll-tube method for the cultivation of strict anaerobes. Methods Microbiol 3B, 117-132.

Huss, V. A. R., Festl, H. \& Schleifer, K. H. (1983). Studies on the spectrometric determination of DNA hybridization from renaturation rates. Syst Appl Microbiol 4, 184-192.

Jahnke, K.-D. (1992). Basic computer program for the evaluation of spectroscopic DNA renaturation data from GILFORD Syst 
2600 spectrometer on a PC/XT/AT type personal computer. $J$ Microbiol Methods 15, 61-73.

Jones, B. E., Grant, W. D., Duckworth, A. W. \& Owenson, G. G. (1998). Microbial diversity of soda lakes. Extremophiles 2 , 191-200.

Jukes, T. H. \& Cantor, C. R. (1969). Evolution of protein molecules. In Mammalian Protein Metabolism, pp. 21-132. Edited by H. N. Munro. New York: Academic Press.

Keller, M., Braun, F.-J., Dirmeier, R., Hafenbradl, D., Burggraf, S., Rachel, R. \& Stetter, K. O. (1995). Thermococcus alcaliphilus $\mathrm{sp.}$ nov., a new hyperthermophilic archaeum growing on polysulfide at alkaline pH. Arch Microbiol 164, 390-395.

Krulwich, T. A. (1982). The fine structure of obligately alkalophilic bacilli. FEMS Microbiol Lett 13, 299-301.

Krulwich, T. A. \& Guffanti, A. A. (1989). Alkalophilic bacteria. Annu Rev Microbiol 43, 435-463.

Krulwich, T. A, Guffanti, A. A. \& Seto-Young, D. (1990). pH homeostasis and bioenergetic work in alkalophiles. FEMS Microbiol Rev 6, 271-278.

Lamed, R., Naimark, J., Morgenstern, E. \& Bayer, E. A. (1987). Specialized cell surface structures in cellulolytic bacteria. $J$ Bacteriol 169, 3792-3800.

Li, Y., Mandelco, L. \& Wiegel, J. (1993). Isolation and characterization of a moderately thermophilic anaerobic alkaliphile, Clostridium paradoxum sp. nov. Int J Syst Bacteriol 43, 450-460.

Li, Y., Engle, M., Weiss, N., Mandelco, L. \& Wiegel, J. (1994). Clostridium thermoalcaliphilum sp. nov., an anaerobic and thermotolerant facultative alkaliphile. Int J Syst Bacteriol 44, 111-118.

Lolkema, J. S, Speelmans, G. \& Konings, W. N. (1994). $\mathrm{Na}^{+}-$ coupled versus $\mathrm{H}^{+}$-coupled energy transduction in bacteria. Biochim Biophys Acta 1187, 211-215.

Macy, J. M, Snellen, J. E. \& Hungate, R. E. (1972). Use of syringe methods for anaerobiosis. Am J Clin Nutr 25, 1318-1323.

Maeda, M. \& Taga, N. (1980). Alkalotolerant and alkalophilic bacteria in seawater. Mar Ecol Prog Ser 2, 105-108.

Mesbah, M., Premachandran, U. \& Whitman, W. B. (1989). Precise measurement of the $\mathrm{G}+\mathrm{C}$ content of deoxyribonucleic acid by high-performance liquid chromatography. Int J Syst Bacteriol 39, 159-167.

Nielsen, P., Fritze, D. \& Priest, F. G. (1995). Phenetic diversity of alkaliphilic Bacillus strains: proposal for nine new species. Microbiology 141, 1745-1761.
Prowe, S. G., van de Vossenberg, J. L. C. M., Driessen, A. J. M., Antranikian, G. \& Konings, W. N. (1996). Sodium-coupled energy transduction in the newly isolated thermoalkaliphilic strain LBS3. J Bacteriol 178, 4099-4104.

Rainey, F. A. \& Stackebrandt, E. (1993). 16S rDNA analysis reveals phylogenetic diversity among the polysaccharolytic clostridia. FEMS Microbiol Lett 113, 125-128.

Rainey, F. A., Dorsch, M., Morgan, H. W. \& Stackebrandt, E. (1992). 16S rDNA analysis of Spirochaeta thermophila: position and implications for the systematics of the order Spirochaetales. Syst Appl Microbiol 16, 224-226.

Ravot, G., Ollivier, B., Margot, M., Patel, B. K. C., Crolet, J.-L., Fardeau, M.-L. \& Garcia, J.-L. (1995). Thiosulfate reduction, an important physiological feature shared by the members of the order Thermotogales. Appl Environ Microbiol 61, 2053-2055.

Smibert, R. M \& Krieg, N. R. (1994). Phenotypic characterization. In Methods for General and Molecular Bacteriology, pp. 607-654. Edited by P. Gerhardt, R. G. E. Murray, W. A. Wood \& N. R. Krieg. Washington, DC: American Society for Microbiology.

Speelmans, G., Poolman, B. \& Konings, W. N. (1995). $\mathrm{Na}^{+}$as coupling ion in energy transduction in extremophilic bacteria and archaea. World J Microbiol Biotechnol 11, 58-70.

Spurr, A. R. (1969). A low-viscosity epoxy resin embedding medium for electron microscopy. J Ultrastruct Res 26, 31-43.

Tindall, B. J. (1990a). A comparative study of the lipid composition of Halobacterium saccharovorum from various sources. Syst Appl Microbiol 13, 128-130.

Tindall, B. J. (1990b). Lipid composition of Halobacterium lacusprofundi. FEMS Microbiol Lett 66, 199-202.

Valentine, R. C., Shapiro, B. M. \& Stadtman, E. R. (1968). Regulation of glutamine synthetase. XII. Electron microscopy of the enzyme from Escherichia coli. Biochemistry 7, 2143-2152.

Venable, J. H. \& Coggeshall, R. (1965). A simplified lead citrate stain for use in electron microscopy. J Cell Biol 25, 407-408.

Zhilina, T. N. \& Zavarzin, G. A. (1994). Alkaliphilic anaerobic community at pH 10. Curr Microbiol 29, 109-112.

Zhilina, T. N., Zavarzin, G. A., Rainey, F., Kevbrin, V. V., Kostrikina, N. A. \& Lysenko, A. M. (1996). Spirochaeta alkalica sp. nov., Spirochaeta africana sp. nov., and Spirochaeta asiatica sp. nov., alkaliphilic anaerobes from the continental soda lakes in Central Asia and the East African Rift. Int J Syst Bacteriol 46, 305-312. 